\title{
Perlindungan Konsumen dan Kualitas Pelayanan Transportasi Online di Kota Tangerang Selatan
}

\author{
Pendi Ahmad ${ }^{1}$, Bima Guntara ${ }^{2}$, Dadang $^{3}$ \\ ${ }^{1,2,3}$ Program Studi D-III Sekretari Universitas Pamulang \\ Jalan Raya Puspiptek, Buaran, Kec. Pamulang, Kota Tangerang Selatan, Banten 15310 \\ Correspondence email: dosen02099@unpam.ac.id ${ }^{1}$, dosen02148@unpam.ac.id ${ }^{2}$, dosen02105@unpam.ac.id ${ }^{3}$
}

\begin{abstract}
Abstrak. Perkembangan zaman serta derasnya globalisasi yang semakin cepat membuat manusia membutuhkan sarana transportasi yang memadai sehingga berkembanglah sebuah teknologi di bidang transportasi berbasis online dengan menggunakan aplikasi via smartphone. Berdasarkan Peraturan Menteri Perhubungan Republik Indonesia Nomor 118 Tahun 2018 Tentang Penyelengaraan Kendaraan Sewa dan Peraturan Menteri Perhubungan Nomor 12 Tahun 2019 Tentang Perlindungan Keselamatan Pengguna Sepeda Motor Yang Digunakan Untuk Kepentingan Masyarakat, maka Transportasi online kini menjadi sebuah terobosan baru dan alternatif dalam hal pemenuhan kebutuhan masyarakat yang tidak memiliki kendaraan pribadi seperti yang terjadi pada masyarakat di Kota Tangerang Selatan. Akan tetapi, kehadiran transportasi online di masyarakat melupakan sesuatu hal yang begitu penting yakni perlindungannya sebagai konsumen. Penelitian ini bertujuan untuk mengetahui perlindungan konsumen bagi pengguna jasa transportasi online di Kota Tangerang Selatan sesuai Undang-Undang Nomor 8 Tahun 1999 Tentang Perlindungan Konsumen dan mengetahui kualitas pelayanan transportasi online di Kota Tangerang Selatan. Metode penelitian menggunakan metode kualitatif dengan memakai pendekatan yuridis empiris. Sampel data diambil dari informan kunci seperti PT. Aplikasi Karya Anak Bangsa (Go-Jek), PT. Solusi Transportasi Indonesia (Grab), pengemudi transportasi online, dan tentunya masyarakat Kota Tangerang Selatan yang terlibat langsung dalam terselenggaranya perlindungan konsumen dan kegiatan pelayanan pada transportasi online di Kota Tangerang Selatan. Sedangkan informan pendukung pada penelitian ini adalah Polres Kota Tangerang Selatan dan Dinas Perhubungan Kota Tangerang Selatan sebagai instansi pemerintah yang secara tidak langsung mengetahui perlindungan konsumen dan kualitas pelayanan transportasi online di Kota Tangerang Selatan. Hasil penelitian menemukan bahwa perlindungan konsumen terhadap pengguna transportasi online di Kota Tangerang Selatan sudah cukup baik hal ini terlihat dari hasil wawancara ke penyedia jasa transportasi online seperti Gojek dan Grab sudah menerapkan SOP (Standar Operational Procedure) ketika konsumen mengalami kerugikan baik formil maupun materil dan juga tidak adanya laporan dari masyarakat kepada Polres Tangerang Selatan yang merasa dirugikan sebagai konsumen transportasi online. Selain itu kualitas pelayanan transportasi online di Kota Tangerang Selatan sudah cukup baik, namun masih ditemukannya beberapa keluhan konsumen seperti pengemudi meminta untuk dibatalkan, pengemudi membatalkan secara sepihak, pengemudi terlalu lama datang untuk menjemput, pengemudi menggunakan kendaraan yang berbeda, dan waktu sampai tujuan yang lebih lama dibandingkan estimasi waktu yang ada di aplikasi.
\end{abstract}

Kata Kunci: Perlindungan Konsumen; Kualitas Pelayanan; Transportasi Online

\begin{abstract}
The development of the times and the rapid pace of globalization that is getting faster make humans need adequate transportation facilities so that a technology in the field of online-based transportation has developed using an application via a smartphone. Based on the Regulation of the Minister of Transportation of the Republic of Indonesia Number 118 of 2018 concerning the Administration of Rental Vehicles and Regulation of the Minister of Transportation Number 12 of 2019 concerning Safety Protection of Motorbike Users Used in the Interest of the Community, online transportation is now a new and alternative breakthrough in fulfilling the needs of the public. do not have private vehicles as happened to the community in South Tangerang City. However, the presence of online transportation in the community forgets something that is so important, namely its protection as a consumer. This study aims to determine consumer protection for users of online transportation services in South Tangerang City according to Law Number 8 of 1999 concerning Consumer Protection and to determine the quality of online transportation services in South Tangerang City. The research method uses qualitative methods using an empirical juridical approach. Data samples were taken from key informants such as PT. Karya Anak Bangsa (Go-Jek) Application, PT. Indonesian Transportation Solutions (Grab), online transportation drivers, and of course the people of South Tangerang City who are directly involved in the implementation of consumer protection and service activities on online transportation in South Tangerang City. Meanwhile, the supporting informants in this study were the South Tangerang City Police and the South Tangerang City Transportation Agency as government agencies that indirectly knew about consumer protection and the quality of online transportation services in South Tangerang City. The results of the study found that consumer protection for online transportation users in South Tangerang City was quite good, this can be seen from the results of interviews with online transportation service providers such as Gojek and Grab that have implemented SOPs (Standard Operational Procedures) when consumers experience losses both formal and material and also There are no reports from the public to the South Tangerang Police who feel aggrieved as a consumer of online transportation. In addition, the quality of online transportation services in South Tangerang City is quite good, but there are still some consumer complaints such as the driver asking to be canceled, the driver canceling unilaterally, the driver coming too long to pick up, the driver using a different vehicle, and the time to arrive at a different destination. longer than the estimated time in the application.
\end{abstract}


Pendi Ahmad, Bima Guntara dan Dadang, Perlindungan Konsumen dan Kualitas Pelayanan Transportasi Online di Kota Tangerang Selatan

Keywords: Consumer Protection; Service Quality; Online Transportation

\section{PENDAHULUAN}

Di zaman modern sekarang ini lahirlah sebuah moda transportasi baru berbasis online yang timbul akibat berkembangnya IPTEK (Ilmu Pengetahuan dan Teknologi). Kemunculan transportasi online begitu menarik perhatian masyarakat. Hadirnya transportasi online, secara berangsur membuat masyarakat meninggalkan transportasi konvensional yang sejak dulu digunakan oleh masyarakat. Kebutuhan jasa transportasi online yang begitu signifikan, maka diperlukan sebuah pelayanan yang berkualitas serta inovatif. Inovasi disini tidak sekedar menciptakan atau membuat sesuatu yang baru, tetapi juga harus menghasilkan produk actual atau outcome (hasil). Sebagai pengguna jasa dari transportasi online, maka sudah seharusnya masyarakat mendapat jaminan pelayanan serta perlindungan konsumen sesuai dengan Undang-Undang Nomor 8 Tahun 1999 Tentang Perlindungan Konsumen. Namun disisi lain, tidak sedikit pengguna jasa transportasi online selaku konsumen tidak mendapatkan haknya sebagai konsumen. Perlindungan konsumen sesuatu hal yang perlu terus ditingkatkan karena tidak terlepas dengan kesejahteraan masyarakat dalam kaitannya berkembang transaksi perdagangan di zaman serba modern saat ini. Berdasarkan penjelasan diatas maka perlunya perlindungan hukum pengguna jasa transportasi online serta jenis-jenis angkutan lainnya dalam hal keselamatan angkutan dan tanggung jawab pengangkut (Shidarta, 2000). Namun nyatanya sering ditemui pengemudi angkutan melakukan tindakan yang menimbulkan kerugian bagi konsumen dalam hal ini penumpang, baik secara materiil maupun immateriil.

\section{METODE}

Pendekatan dalam pelitian ini ialah pendekatan penelitian kualitatif (Qualitatif Research) dengan tujuan memperkaya hasil penelitian kuantitaif. Penelitian kualitatif dilaksanakan untuk melahirkan pengetahuan melalui literatur ilmiah melalui suatu proses menyelidiki suatu gejala sosial yang ada di masyarakat. Sehingga peneliti dapat membuat gambaran kompleks, meneliti kata-kata, laporan terinci dari pandangan responden dan melakukan studi pada situasi yang alami.

Penelitian kualitatif digunakan untuk mencari sesuatu hal yang tersembunyi, untuk mengetahui interaksi sosial di masyarakat, mengembangkan teori yang berkaitan dengan penelitian ini, memastikan keakuratan data dan sejarah perkembangan kehidupan masyarakat dalam hal ini bagaimana perlindungan konsumen dan kualitas pelayanan transportasi online di Kota Tangerang Selatan.

Penelitian ini akan dilakukan di Kota Tangerang Selatan yang menjadi objek dan fokus utama peneliti dalam melihat dan mengetahui bagaimana konsep perlindungan konsumen dan kualitas pelayanan transportasi online di Kota Tangerang Selatan.

Data yang dipakai dalam penilitian ini yaitu data primer maupun sekunder. Data primer yaitu data yang penulis kumpulkan dari hasil kajian lapangan dengan observasi, kuisioner, dan wawancara dengan pihak terkait yaitu PT. Aplikasi Karya Anak Bangsa (Go-Jek), PT. Solusi Transportasi Indonesia (Grab), Polres Kota Tangerang Selatan, Dinas Perhubungan Kota Tangerang, Pengemudi Transportasi Online, dan Masyarakat Kota Tangerang Selatan.

Data sekunder ialah data yang didapat dari kepustakaan, Undang-undang serta buku-buku, artikel-artikel dan pendapat ahli yang berhubungan dan berkaitan pada permasalahan yang akan dibahas pada penelitian ini sehingga dapat terkumpul satu data yang akurat.

Data-data yang telah penulis kumpulkan, baik primer sekunder telah penulis analisa dengan teknik Komparasi Konstan (Grounded Theory Research) yakni mencoba mengkaitkan/menghubungkan antara fakta-fakta didapat dilapangan dengan data normatif yang tersedia khususnya dengan Undang-Undang Nomor 8 Tahun 1999 Tentang Perlindungan Konsumen sehingga penulis akan dapat menentukan hipotesis dan kesimpulan terhadap penelitian ini.

\section{HASIL DAN PEMBAHASAN}

Dalam menjalankan usahanya, perusahaan pasti akan bersentuhan dengan pihak lain salah satunya konsumen. Menjadi pertanyaan ketika usaha tersebut justru menimbulkan kerugian kepada konsumen baik secara langsung ataupun tidak langsung maupun kerugian fisik dan ekonomis. Salah satu contoh kerugian fisik misalnya makanan yang dikonsumsi ternyata membahayakan kesehatan atau sudah kadaluwarsa. Sedangkan kerugian ekonomis ketika konsumen membeli barang/jasa yang tidak sesuai dengan dijanjikannya (Absori, 2014). Lalu terhadap fenomena diatas bagaimana aturan hukumnya, terutama mengenai tanggung jawab perusahaan. Pengusaha dimintai pertanggungjawabannya ketika lahir akibat karena perbuatan atau kelalaian pada orang atau pihak lain. UndangUndang Perlindungan Konsumen lahir karena dilatarbelakangi banyaknya permasalahan yang terjadi antara konsumen dengan pengusaha dalam melakukan usahanya tanpa memperhatikan mutu yang hanya menguntungkan dirinya dan menimbulkan kerugian konsumen.

Keterkaitan antara perusahaan transportasi online dengan driver adalah hubungan kemitraan yang tidak lepas dari hukum perjanjian antara para pihak, yang didasarkan pada asas kebebasan berkontrak. Melalui perjanjian dapat 
diketahui hak dan kewajiban masing-masing pihak, termasuk konsekuensinya apabila terjadi wanprestasi. Ketentuan hukum yang berkaitan dengan tanggung jawab perusahaan yang lalai dan menyebabkan kerugian pada pihak konsumen dapat dilihat pada Pasal 1365 Kitab Undang-Undang Hukum Perdata (KUHPerdata) dengan mewajibkan pihak perusahaan untuk membayar ganti rugi dan Pasal 1865 KUHPerdata dengan kewajiban pihak yang telah menuduh (konsumen) untuk membuktikkannya. Dalam hukum perdata upaya untuk membuktikan dan menentukan siapa yang telah melakukan perbuatan melawan hukum, menurut ketentuan Pasal 1243 dan Pasal 1365 KUHPerdata diatur azaz liability based on fault. Dalam pasal tersebut unsur kesalahan bersifat menentukan pertanggungjawaban yang berarti bila tidak terbukti adanya kesalahan tidak ada kewajiban untuk memberi ganti rugi. Kemudian dalam Pasal 19 ayat (1) Undang-Undang Nomor 8 Tahun 1999 Tentang Perlindungan Konsumen, dimana pelaku usaha bertanggung jawab memberikan ganti rugi atas kerusakan, pencemaran, dan/atau kerugian konsumen akibat mengkonsumsi barang dan/jasa yang dihasilkan atau diperdagangkan. Bentuk ganti rugi dijelaskan melalui Pasal 19 ayat (2) UU No.8 Tahun 1999 yakni dapat berupa pengembalian uang, atau penggantian barang dan/atau jasa yang sejenis atau setara nilainya, atau perawatan kesehatan dan/atau pemberian santunan. Pemberian ganti rugi tidak menghapuskan adanya tuntutan pidana. Apabila pelaku usaha hendak melepaskan diri dari tanggung jawab maka diwajibkan untuk melakukan pembuktian.

Tanggung jawab yang berkaitan dengan bidang usaha perdagangan jasa dalam konteks perlindungan konsumen diatur dalam Pasal 26 UU No.8 Tahun 1999, dimana pelaku usaha yang memperdagangkan jasa wajib memenuhi jaminan dan/atau garansi yang disepakati dan/atau yang diperjanjikan. Gojek dan Grab merupakan usaha yang bergerak di bidang jasa transportasi online yang harus tunduk aturan yang melekat padanya. Perusahaan transportasi online biasanya menguraikan jaminan dan/atau garansi atas jasa yang diberikan melalui syarat dan ketentuan misalnya, perusahaan Gojek yang berupaya memperhatikan keamanan, kenyamanan, hingga memastikan bahwa konsumen terlindungi dalam perjalanan ketika menggunakan layanannya dari musibah kecelakaan yang mungkin terjadi. Oleh karena itu, Gojek bekerja sama dengan Allianz, memberikan manfaat perlindungan berupa jaminan keselamatan secara maksimal, mulai dari penjemputan hingga tiba di lokasi tujuan. Untuk konsumen yang sedang dalam perjalanan bersama GoRide, akan secara otomatis mendapatkan manfaat perlindungan asuransi secara gratis tanpa perlu membayar biaya premi polis maupun biaya tambahan lainnya. Seluruh biaya premi menjadi tanggungan Gojek. Besarnya reimbursement atau uang tunai nilai pertanggungan yang tertera akan ditransfer melalui akun bank yang terdaftar.

Berikut detail manfaat dan nilai pertanggungan yang didapatkan:

a. Kehilangan atau kerusakan barang pribadi karena tindak kriminal (begal), jaminan asuransi ini diberikan jika penumpang mengalami tindak kriminal yang menyebabkan kehilangan atau kerusakan barang pribadi. Nilai pertanggungan ini senilai hingga Rp1.000.000 per kejadian.

b. Biaya pengobatan, jaminan asuransi ini diberikan jika penumpang mengalami kecelakaan yang menyebabkan cedera dan membutuhkan perawatan medis. Biaya pengobatan yang diberikan termasuk biaya kamar (jika rawat inap) dan obat-obatan. Nilai pertanggungan biaya pengobatan senilai hingga Rp5.000.000 per kejadian.

c. Cacat permanen, jaminan asuransi ini diberikan jika penumpang mengalami kecelakaan dalam satu kejadian yang menyebabkan hilangnya salah satu anggota tubuh, tidak dapat berfungsi kembali, dan telah dinyatakan cacat tetap oleh dokter. Nilai pertanggungan cacat permanen sesuai dengan persentase untuk setiap bagian anggota tubuh senilai hingga Rp50.000.000 per kejadian.

d. Kematian karena kecelakaan, santunan kematian diberikan sebagai pertanggungan karena kecelakaan lalu lintas dalam satu kejadian senilai Rp50.000.000 serta biaya pemakaman senilai Rp1.000.000

Pihak yang ditanggung oleh polis asuransi adalah:

a. Penumpang yang terdaftar di aplikasi Gojek, membayar serta memesan layanan transportasi GoRide

b. Penumpang GoRide bukan pemilik akun Gojek, yang layanan transportasinya dipesankan oleh pemilik akun Gojek

Pada saat konsumen melakukan pengajuan klaim, semua bukti kejadian dan dokumen yang diperlukan seperti nomor pemesanan, foto kartu identitas diri, resume medis, kuitansi atau bukti biaya rumah sakit asli, laporan kecelakaan dari Kepolisian atau Berita Acara Polisi (BAP), dan dokumen lain diserahkan dalam bentuk soft copy (foto) dan dikirimkan melalui form online pada saat pengajuan klaim. Setelah mengisi formulir pengajuan klaim pada form online, pihak penyelenggara asuransi akan menghubungi untuk meminta jawaban beberapa pertanyaan terkait kejadian yang dialami untuk memastikan kelengkapan informasi tersebut (seperti apa, siapa, mengapa, kapan, di mana dan bagaimana kronologi kejadian). Pengajuan klaim terkait kecelakaan ketika menggunakan layanan GoRide harus dilaporkan melalui form klaim online paling lambat 30 hari sejak terjadi kecelakaan. Pengajuan klaim akan ditinjau terlebih dahulu oleh pihak insurtech hingga dinyatakan lengkap. Mereka akan menginformasikan melalui email apabila dokumen dinyatakan lengkap dan siap untuk diproses, atau jika dokumen dinyatakan belum lengkap. Untuk 
itu, pada saat mengisi form klaim, mohon pastikan bahwa alamat email yang ditulis merupakan email yang sering kamu gunakan. lengkap:

Nilai pertanggungan atau reimbursement akan kamu terima dalam waktu berikut sejak dokumen dinyatakan

a. 5 (lima) hari kerja untuk nilai pertanggungan yang tidak mengakibatkan kematian

b. 7 (tujuh) hari kerja untuk nilai pertanggungan yang mengakibatkan kematian

Klaim asuransi konsumen menjadi tidak berlaku atau ditolak apabila:

a. Terlibat pada kejadian perang, operasi militer dan tindakan huru hara

b. Semua pre-existing condition atau kondisi yang sudah ada sebelumnya, kelainan/cacat yang dibawa dari lahir, dan penyakit turunan

c. Segala tindakan ilegal dan tidak sesuai dengan kaidah hukum oleh pihak yang diasuransikan

d. Semua kejadian yang melibatkan pihak diasuransikan termasuk kondisi medis kehamilan, melahirkan, atau keguguran, aborsi, kondisi sebelum melahirkan serta setelah melahirkan dan komplikasi yang terjadi akibat penyakit menular

e. Melakukan kegiatan yang berbahaya

f. Kasus-kasus di mana tindak kejahatan dilakukan oleh driver, harap segera melaporkan hal tersebut kepada kami di Call Center CCU: (021) 50251110 dan kami akan segera menanganinya.

g. Gangguan kejiwaan, saraf dan berbagai kondisi di bawah pengaruh alkohol atau obat-obatan (selain yang telah disarankan resep dari tenaga ahli)

h. Reaksi nuklir, radiasi, atau kontaminasi radioaktif

i. Terorisme nuklir, kimia, atau biologi

j. Bunuh diri atau luka yang disengaja

k. Pihak yang diasuransikan memiliki kadar alkohol dalam darah lebih tinggi dari yang telah tertera dalam aturan mengemudi

1. Pihak yang diasuransikan tidak melakukan usaha-usaha untuk menghindari kecelakaan

Adapun Grab salah satu perusahaan jasa transportasi online juga memberikan jaminan bagi driver dan penumpang bekerjasama dengan perusahaan asuransi global. Salah satu produk asuransi pertama adalah asuransi Grup untuk Grab. Kecelakaan yang mencakup semua perjalanan Grab di wilayah tersebut. Ini adalah yang pertama dari asuransi kecelakaan diri untuk pengemudi dan penumpang di industri ride sharing, tidak ada pemotongan dan biaya tambahan untuk setiap perjalanan Grab.

Siapa yang ditanggung oleh Polis ini:

a. Pengemudi yang memenuhi syarat yang terdaftar di Grab

b. Penumpang yang memesan dan membayar yang telah terdaftar untuk berekendara dengan Grab yang terdaftar.

Asuransi pribadi kami dirancang untuk memberi kompensasi Tertanggung, untuk cedera tubuh yang timbul dari kecelakaan Grab, tidak peduli siapa yang salah. Pihak Asuransi akan mengganti Tertanggung untuk jenis berikut klaim, hingga batas yang ditentukan dalam Kebijakan:

\section{a. Kematian}

Tunjangan pemakaman disediakan sebagai manfaat kematian tambahan.

\begin{tabular}{|c|c|c|}
\hline Tertanggung & GrabCar & GrabBike \\
\hline Pengemudi & Rp130.000.000 & Rp50.000.000 \\
\hline Penumpang & Rp130.000.000 & Rp50.000.000 \\
\hline
\end{tabular}

\section{b. Cacat Permanen}

Seseorang yang dipertanggungkan menderita cedera selama perjalanan yang menghasilkan cacat permanen. Kami akan mengganti kerugian didasarkan pada tingkat kerusakan atau cacat, seperti yang ditetapkan oleh kebijakan mengenai persentase yang relevan untuk setiap bagian dari tubuh.

\begin{tabular}{|c|c|c|}
\hline Tertanggung & GrabCar & GrabBike \\
\hline Pengemudi & Rp13.000.000 & Rp25.000.000 \\
\hline Penumpang & Rp13.000.000 & Rp25.000.000 \\
\hline
\end{tabular}




\section{c. Biaya Pengobatan}

Seseorang yang dipertanggungkan menderita cedera selama perjalanan yang menimbulkan biaya untuk perawatan medis. Kami akan mengganti Tertanggung untuk biaya pengobatan pertama sesuai dengan jumlah tagihan yang dibebankan dengan limit seperti dibawah ini:

\begin{tabular}{|c|c|c|}
\hline Tertanggung & GrabCar & GrabBike \\
\hline Pengemudi & Rp130.000.000 & Rp25.000.000 \\
\hline Penumpang & Rp130.000.000 & Rp50.000.000 \\
\hline
\end{tabular}

Jika tertanggung mengajukan klaim kepada pihak Asuransi lain maka Grab hanya akan bertanggung jawab atas kelebihan jumlah tidak terbayarkan dari asuransi lain seperti pengecualian umum berlaku, misalnya perang, militer atau operasi, setiap tindakan yang disengaja dan melanggar hukum, semua komplikasi yang timbul dari kondisi medis kehamilan terkait atau yang sudah ada, pengaruh alkohol atau obat-obatan, terlibat dalam balap liar dan perawatan gigi. Silakan laporkan kecelakaan ke layanan pelanggan dan polisi segera jika konsumen terlibat dalam kecelakaan selama perjalanan Bersama Grab. Layanan pelanggan tersedia untuk menanggapi masalah apapun. Konsumen akan diminta untuk menjawab beberapa pertanyaan (Siapa, Apa, Kapan, Dimana, Mengapa \& Bagaimana) untuk memastikan informasi kecelakaan. Layanan pelanggan akan memberitahu tentang proses klaim, serta semua dokumen terkait yang diperlukan untuk mengajukan klaim dengan perusahaan asuransi kami. Semua kecelakaan harus dilaporkan kepada perusahaan asuransi dengan mengirimkan laporan klaim dalam jangka waktu perjanjian ditetapkan, selambat-lambatnya 30 hari dari kecelakaan terjadi. Semua bukti yang relevan dan dokumen yang diperlukan, seperti copy identitas diri, resume medis, kuitansi/ bukti biaya rumah sakit asli, laporan kecelakaan dari kepolisian (jika ada), bukti pemesanan Grab, dll harus diserahkan kepada perusahaan asuransi.

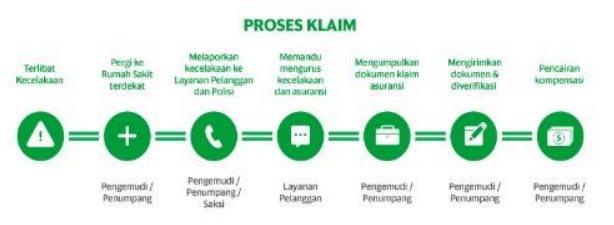

Gambar 1

Proses Klaim Grab

Pasal 26 UU No.8 Tahun 1999, menyebutkan jaminan dan/atau garansi atas jasa wajib dipenuhi oleh perusahaan dalam hal ini transportasi online. Tidak sekedar penggantian kerugian, kompensasi, dan santunan dengan uang akan tetapi, perusahaan turut bertanggung jawab untuk memberikan hukuman kepada. Maka dari itu perlu dilakukan seleksi yang menyeluruh dan diberikan pelatihan terlebih dahulu sebelum mempekerjakan calon driver.

Penulis juga berkesempatan melakukan wawancara kepada instansi terkait dalam hal ini Polres Tangerang Selatan terkait perlindungan konsumen pengguna transportasi online di Kota Tangerang Selatan, berdasarkan informasi dari Kabag Ops Satreskrim Polres Tangerang Selatan atas nama Kompol Winarno bahwasannya selama ini diwilayah hukum Kota Tangerang Selatan belum pernah menerima laporan atau aduan dari masyarakat pengguna transportasi online.

Hadirnya transportasi online memang sangat membantu masyarakat dalam memenuhi aktivitasnya sehari-hari. Di samping metode pembayaran yang lebih canggih, praktis, murah dan banyak promo, konsumen jangan hanya memikirkan kemudahan saja tanpa memikirkan keselamatan. Menurut Latipah Hendarti "Educational for sustainable consumption consists of the acquisition of knowledge, attitudes and skills necessary for functioning in today's soecity. It is responsibility learning which aims to contribute to the individual's ability to manage his own life while also participating in the stewardship of the global soecity's collective life." Intinya konsumen harus memiliki edukasi agar dapat menjadi konsumen yang bijak dan dapat berpartisipasi dalam kehidupan masyarakat yang berkelanjutan.

Dari hasil wawancara yang dilakukan oleh penulis kepada 500 responden pengguna jasa transportasi online (konsumen) disekitar kota Tangerang Selatan sebanyak 310 orang atau $62 \%$ konsumen menyatakan layanan yang diberikan sudah diberikan baik, namun sebanyak 190 konsumen atau $38 \%$ konsumen memiliki keluhan yang dialami saat menggunakan transportasi online diantaranya ialah pengemudi meminta untuk dibatalkan, pengemudi membatalkan secara sepihak, pengemudi terlalu lama datang untuk menjemput, pengemudi menggunakan kendaraan yang berbeda, dan waktu sampai tujuan yang lebih lama dibandingkan estimasi waktu yang ada di aplikasi. Berikut gambar hasil wawancara: 


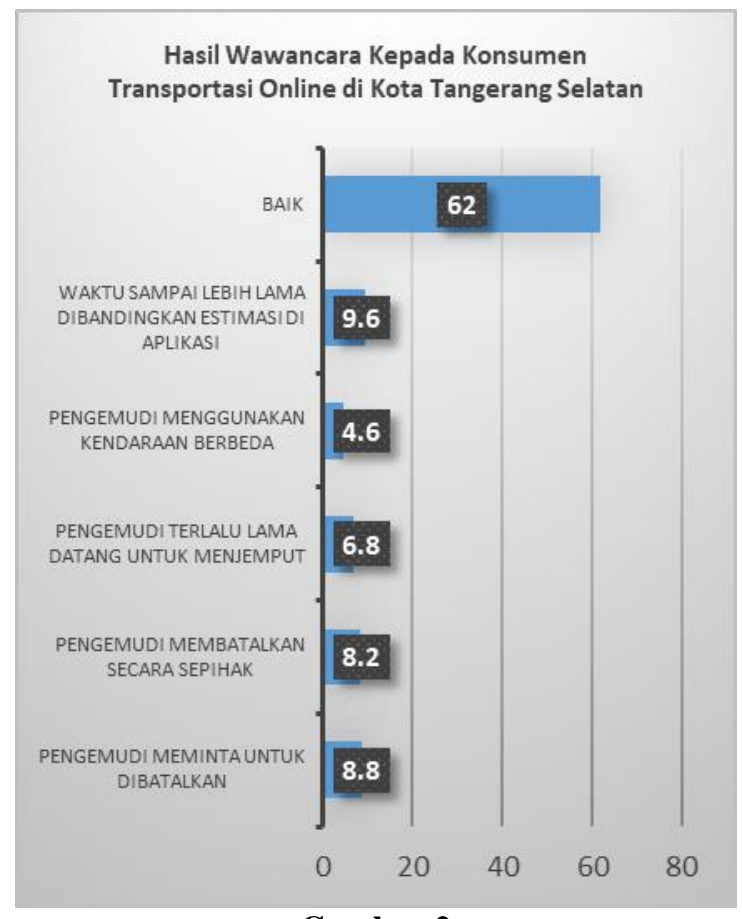

Gambar 2

Keluhan Konsumen Transportasi Online

Dari gambar diatas terlihat bahwa sebagian besar masyarakat Kota Tangerang Selatan merasa layanan yang diterima sebagai konsumen sudah baik, walaupun masih ada beberapa hal yang dikeluhkan oleh konsumen. Persentase keluhan waktu sampai lebih lama dibandingkan estimasi di aplikasi lebih tinggi dibandingkan keluhan-keluhan lain yang ada. Peneliti mencoba menyusuri dengan melakukan wawancara baik kepada pengemudi maupun konsumen transportasi online. Berdasarkan hasil wawancara kepada salah satu pengemudi transportasi online di Kota Tangerang Selatan atas nama Rio, dia menjelaskan bahwa yang menjadi penyebab waktu sampai lebih lama dibandingkan estimasi waktu di aplikasi dikarenakan volume kendaraan di Kota Tangerang Selatan pada jam-jam tertentu sangat padat sehingga menyebabkan kemacetan. Hal senada juga disampaikan oleh salah satu konsumen transportasi online di Kota Tangerang Selatan atas nama Fanny (Mahasiswa Universitas Pamulang), dia menjelaskan bahwa memang di jam-jam tertentu terutama di pagi dan sore hari jalanan macet sehingga waktu sampai tujuan lebih lama dari estimasi waktu yang ada di aplikasi. Keluhan lain yang dialami oleh konsumen transportasi online ialah pengemudi meminta untuk dibatalkan ataupun membatalkan secara sepihak. Seperti yang dialami oleh Hadi (Dosen Universitas Pamulang), dia menjelaskan bahwa pernah beberapa kali pengemudi meminta untuk dibatalkan ataupun membatalkan secara sepihak tanpa penjelasan, hal ini tentu membuat Hadi mengulang memesan beberapa kali hingga akhirnya ada pengemudi yang mau untuk mengantarkan saya pulang. Selain itu ada juga Sasha (Karyawati Mall di BSD), dia juga mengeluhkan, bahwa pengemudi terlalu lama datang untuk menjemput, hal ini dia maklumi karena memang jalan di sekitaran tempat dia bekerja macet. Peneliti mencoba mengkonfirmasi kepada pengemudi transportasi online di Kota Tangerang Selatan atas nama Kelik mengenai keluhan yang dialami oleh para konsumen tentang kenapa pengemudi meminta untuk dibatalkan ataupun membatalkan secara pihak dan juga terlalu lama datang untuk menjemput, dia menjelaskan bahwa hal ini dilakukan oleh pengemudi karena tujuan yang dituju oleh konsumen melewati area kemacetan yang padat sehingga hal itu dilakukan oleh pengemudi untuk mengurangi kerugian karena kemacetan yang dialami selama perjalanan tersebut.

Berdasarkan informasi diatas penulis mencoba mengkonfirmasi ke instansi terkait dalam hal ini Dinas Perhubungan Kota Tangerang Selatan atas nama Nini Apriani bagian DalOps Dishub Tangerang Selatan mengenai titik kemacetan yang sering terjadi di Kota Tangerang Selatan, setidaknya ada 40 titik kemacetan yang sering terjadi di Kota Tangerang Selatan pada jam-jam tertentu.

Keluhan lain yang dikeluhkan oleh konsumen ialah berbedanya kendaraan yang dipakai oleh pengemudi. Peneliti melakukan wawancara kepada pengemudi transportasi online di Kota Tangerang Selatan atas nama Rizky, dia menjelaskan bahwa memang ada beberapa pengemudi yang menggunakan kendaraan berbeda dikarenakan kendaraannya sedang rusak atau sudah mengganti kendaraan yang baru, namun jumlahnya sedikit. 
Pendi Ahmad, Bima Guntara dan Dadang, Perlindungan Konsumen dan Kualitas Pelayanan Transportasi Online di Kota Tangerang Selatan

\section{SIMPULAN}

Perlindungan konsumen pada pengguna transportasi online sudah cukup baik hal ini terlihat dari adanya tanggung jawab dari penyedia jasa transportasi online kepada konsumen bila mengalami kerugian. Selain itu berdasarkan hasil wawancara kepada para pengguna transportasi online Sebagian besar merasa pelayanan yang diberikan oleh pengemudi sudah baik.

Peneliti memberikan masukan baik kepada penyedia jasa maupun konsumen agar tunduk dan patuh terhadap hak dan kewajibannya masing-masing sesuai Undang-Undang Nomor 8 Tahun 1999 Tentang Perlindungan Konsumen.

\section{DAFTAR PUSTAKA}

\section{Buku}

Absori. (2014). Hukum Ekonomi di Indonesia, Beberapa Aspek Pengembangan Pada Era Liberalisasi Perdagangan. Surakarta: Muhammadiyah University Press.

Latipah Hendarti. (2012). Institutional Strengthening of Education For Suitainable Consumption (ESC), Advancing ESC Policy and Implementation Strategies Mapping Opportunities In Indonesia, YPB \& UNEP.

Mulyana, D. (2003). Metodologi penelitian kualitatif: paradigma baru ilmu komunikasi dan ilmu sosial lainnya. PT Remaja Rosdakarya.

Shidarta. (2000). Hukum Perlindungan Konsumen Indonesia, Jakarta: PT. Grasindo.

Lexy J Moleong. (2008). Metodologi Penelitian Kualitatif. Bandung: Remaja Rosdakarya.

\section{Peraturan Perundang-undangan}

Undang-Undang Nomor 8 Tahun 1999 Tentang Perlindungan Konsumen.

Undang-Undang Nomor 19 Tahun 2016 Tentang Perubahan Atas Undang-Undang Nomor 11 Tahun 2008 Tentang Informasi dan Transaksi Elektronik (ITE)

Peraturan Menteri Perhubungan Nomor 118 Tahun 2018 Tentang Penyelengaraan Kendaraan Sewa

Peraturan Menteri Perhubungan Nomor 12 Tahun 2019 Tentang Perlindungan Keselamatan Pengguna Sepeda Motor Yang Digunakan Untuk Kepentingan Masyarakat

\section{Wawancara}

Wawancara dengan Winarno, Kabag Ops Satreskrim Polres Tangerang Selatan, tanggal 19 Mei 2020 di Kota Tangerang Selatan.

Wawancara dengan Radit, Divisi CRI (Critical risk integrity) Gojek, tanggal 04 Juni 2020 di Kantor Layanan Driver Gojek Kemang Jakarta Selatan

Wawancara dengan Karina, Customer Service Grab, tanggal 17 Juni 2020 di Kantor Pusat Grab Jakarta Utara Wawancara dengan Rio, Pengemudi Transportasi Online, tanggal 23 Juni 2020 di Kota Tangerang Selatan. Wawancara dengan Rizky, Pengemudi Transportasi Online, tanggal 05 Agustus 2020 di Kota Tangerang Selatan. Wawancara dengan Fanny, Konsumen Transportasi Online, tanggal 12 Agustus 2020 di Kota Tangerang Selatan. Wawancara dengan Hadi, Konsumen Transportasi Online, tanggal 13 Agustus 2020 di Kota Tangerang Selatan. Wawancara dengan Sasha, Konsumen Transportasi Online, tanggal 14 Agustus 2020 di Kota Tangerang Selatan. Wawancara dengan Kelik, Pengemudi Transportasi Online, tanggal 05 September 2020 di Kota Tangerang Selatan. 